\title{
THE RISE OF COVENANT-LITE LENDING AND IMPLICATIONS FOR ENGLAND'S CORPORATE INSOLVENCY LAW TOOLBOX
}

\section{Introduction}

This article is, so far as the author is aware, the first to examine in detail the implications of the explosion of covenant-lite lending in England after the financial crisis for English corporate insolvency law. As we shall see, covenant-lite loans lack the early warning mechanisms of financial trouble ahead which have traditionally been found in loans to heavily indebted borrowers. Broad concerns for the implications of covenant-lite lending and financial distress have been raised in the broadcast media, 1 in the financial press, 2 and by both Janet Yellen in the US, 3 and the Bank of England in the UK.4 It is clear that this is an issue which matters to all of us. There has been some attempt, in the finance literature, to offer explanations for the phenomenon which may mitigate the concerns but, as identified in the article, the most convincing explanation does not do much to put minds at rest. There has also been some regulatory response but, as the article goes on to show, this response has a very specific objective related to regulated financial institutions which still leaves significant concern for the implications of covenant-lite lending for large employers and for the economy as a whole. One possibility is that more extensive regulatory intervention will follow the increasingly loud sounding of the alarm, but the article identifies why more sustained regulatory intervention is unlikely in the short term. We are left, then, with a serious concern and very little idea of what to do about it.

\footnotetext{
${ }^{1}$ BBC Newsnight 10 December 2014

2 See, for example, Colby Smith, 'Leveraged Loans Are Way Past “Cov-Lite”' Financial Times (London, 16 November 2018)

3 Janet Yellen is an American economist who served as Chair of the Board of Governors of the Federal Reserve System from 2014 to 2018. For her recent comment see Sam Fleming, 'Janet Yellen Sounds Alarm Over Plunging Loan Standards' Financial Times (New York, 17 October 2018)

${ }^{4}$ Caroline Binham, 'BoE Warns Over Growth of Risky Corporate Loans' Financial Times (London, 17 October 2018)
} 
This article seeks to make a contribution by identifying what the implications of covenant-lite lending are when a borrower faces financial distress, and why this may mean that covenant-lite borrowers cannot be restructured using the techniques developed to restructure large companies in the decade since the financial crisis. It undertakes a detailed review of why different corporate insolvency tools may be needed to minimise losses from the default of a covenant-lite borrowers, and specifically what those tools are. In this way it seeks to map out areas where English corporate insolvency law may not be well-adapted to the specific challenges which covenant-lite lending poses, so that we can get our toolbox in order before the next cycle of restructuring begins. In other words, it suggests that one positive step we need to take is to make sure that corporate insolvency law is equal to the challenges which covenant-lite lending may pose.

At the time of writing, the UK Government has responded to the Insolvency and Corporate Governance consultation launched in 2016,5 and has proposed three, new tools for the English corporate insolvency law toolbox. However, neither the response nor the consultation analyse why the new tools may be needed. This is perhaps unsurprising because much of the motivation for the reform comes from investors and practitioners who have identified that English corporate insolvency law does not have some of the tools which are readily available in US Chapter 11.6 A similarly motivated reform debate is also happening at the European Commission level.7 Thus the reform proposals are centred on certain, US-centric tools but without too much focus on why we may need them and what we might use them for. There is something to be said for this approach in terms of low cost and speedy reform. Yet the problem with it is that, unless we have identified why we need the tools and what we might use them for, we will find it difficult to work out the detail of their design and how they fit into the rest of our toolbox. This is the second contribution which the article seeks to

\footnotetext{
${ }^{5}$ Department for Business, Energy and Industrial Strategy Insolvency and Corporate Governance Consultation: Government Response 26 August 2018

${ }^{6}$ See, for example, letter from Andrew Wilkinson 'Why Has Carillion Been Allowed to Collapse?' Financial Times (London, 29 January 2018)

7 Proposal for a Directive of the European Parliament and of the Council on preventive restructuring frameworks, second chance and measures to increase the efficiency of restructuring, insolvency and discharge procedures and amending Directive 2012/30/EU
} 
make. By identifying the tools which we need to address the covenant-lite phenomenon, and the specific purposes for which they may be needed, it is hoped that the article will assist in this detailed working out of the English law reform effort.

The article is organised as follows. Part 2 starts with an analysis of the predecessor to covenant-lite leveraged loans: loans containing maintenance financial covenants. Part 3 explains why a covenant-lite loan is different from a financial maintenance covenant loan. It reviews the various explanations for the recent rise of covenant-lite leveraged loans, and concludes that the most convincing explanation does very little to alleviate concerns for the consequences of covenant-lite lending in distress which have been voiced. Part 4 analyses the current regulatory response, and the reasons why this does not address the concerns. This leads, in Part 5, to a detailed analysis of why covenant-lite lending may have the result that the restructuring of large, leveraged borrowers does not follow the same pattern in the next decade as in the last, and of the specific corporate insolvency law tools which may be needed. To the extent that there are gaps in the existing English corporate insolvency law toolbox, Part 6 briefly analyses whether the current reform proposals fill them, and where there are issues with design which may require further thought. Part 7 concludes.

\section{Maintenance Financial Covenants}

In their path finding work in 1976, Jensen and Meckling identified the creditor-director agency problem in distress. 8 When a firm is in financial distress, lenders face the risk that directors will take ever riskier action in an attempt to turn things around and, thus, to save their jobs. This risk-taking behaviour may benefit shareholders who, as the residual owners of the firm, only stand to gain if the firm is able to stay in business. But the risk-seeking behaviour may not be in the best interests of creditors because cash in the business will diminish as the strategies are pursued so that, if the directors are not successful in their mission, creditors will recover less than they would otherwise have done. Thus creditors may very well want the directors to avoid the risky strategies and to follow

\footnotetext{
${ }^{8}$ Michael C Jensen and William H Meckling, 'Theory of the Firm: Managerial Behavior, Agency Costs and Ownership Structure' (1976) Journal of Financial Economics 3(4) 305
} 
more conservative options for the financially distressed firm. In other words, a classic misalignment of incentives emerges.

Law may play some part in reducing the costs associated with the creditor-director agency problem, but has a number of limitations in this regard.9 Thus, Jensen and Meckling posited that lenders will negotiate for protective covenants in the loan agreement which reduce the agency costs of debt.10 A key set of protections are so-called maintenance financial covenants. Maintenance financial covenants set ratios and thresholds for the company's financial performance using 'observable financial metrics' such as debt to EBITDA (earnings before tax, depreciation and amortisation).11 These covenants are tested on an ongoing basis or at specific points in time: in other words, they must be maintained. If a financial covenant is not met when it is tested, then a default will arise under the terms of the loan agreement entitling the lenders to take the same action which they would be entitled to take on a payment default.12 It is unlikely that the lenders will want to exercise these rights immediately, as they risk leading to a value-destructive insolvency filing. The real power of these rights is that they enable the lenders to demand the directors come to the negotiating table, and provide the lenders with the necessary power to influence governance of the company.13

\footnotetext{
${ }^{9}$ In England, section 172(3) of the Companies Act 2006 effectively requires directors to have regard to creditors' interests not only when the company is insolvent, but also when it is of doubtful solvency. However, in practice, many enforcement issues arise. Furthermore, relying on the assets of the directors, even if a successful claim can be made, may be a poor substitute for preventing the risk-seeking behaviour in the first place. The common law regime is supported by the statutory regime of fraudulent and wrongful trading in sections 213 and 214 of the Insolvency Act 1986. In practice, however, both provisions are also fraught with enforcement challenges. Finally, England has a statutory regime for disqualifying directors, either in agreement with the Secretary of State or on an application by the Secretary of State to court, and since the Small Business, Enterprise and Employment Act 2015 it has been possible for the Secretary of State to seek compensation for creditors as part of the disqualification procedure. Nonetheless, this is a state remedy, which relies on the willingness of the Government agency to bring a claim, and the new compensation regime enables the Secretary of State to determine which creditors the compensation should be allocated to, which may very well not be the financial creditors.

10 Jensen and Meckling 'Theory of the Firm' (n 8 above) 333-339

11 The description 'observable financial metrics' is borrowed from Matthew T Billett, Redouane Elkamhi, Latchezar Popov and R Pungaliya, 'Bank Skin in the Game and Loan Contract Design: Evidence from CovenantLite Loans' (2016) 51(3) Journal of Financial and Quantitative Analysis 839, 841

12 This includes terminating the right of the borrower to draw down any further funds under the loan agreement, or accelerating the date of repayment of the loan so that it becomes immediately due and payable ${ }^{13}$ Greg Nini, David C Smith and Amir Sufi, 'Creditor Control Rights, Corporate Governance, and Firm Value' (2012) 25(6) The Review of Financial Studies 1713, 1715; Cem Demiroglu and Christopher M James, 'The Role of Private Equity Group Reputation in LBO Financing' (2010) 96 Journal of Financial Economics 306, 306-307
} 
The late 1990s and the 2000s saw a surge in the number of leveraged buyout transactions led by private equity firms in the UK.14 In a PE leveraged buyout, or LBO, the PE firm establishes a company, or more commonly a group of companies, for the purposes of making an acquisition of a target company and (usually) its group companies.15 The target may be a private company, put up for sale by its existing owners, or a public company.16 The acquisition is usually financed by debt at multiples of earnings of the target group considerably in excess of the average for the industry in question, and a comparatively small equity contribution financed by the private equity firm. The debt is borrowed by the newly established finance company purchaser and, after the transaction, guaranteed and secured by the assets of its acquired operating subsidiaries.17 Intuitively, a highly leveraged capital structure of this type increases the risk of default, because it is likely to demand the allocation of significant amounts of cash to pay interest on the considerable amount of debt, so that a cash flow shock will affect a highly leveraged business more rapidly than a business with less debt. Thus, given the role of maintenance financial covenants in reducing the agency costs of debt, we would expect to find them in a leveraged loan agreement. Yet here we find something of a puzzle. Rather than finding an increased focus on maintenance financial covenants, we find the increasing prevalence of so-called covenant-lite lending in the leveraged buyout space.

A covenant-lite loan has no, or only very few, financial covenants. If it does have financial covenants, these covenants are not tested on an on-going basis, or maintained, but are only triggered if the borrower raises further debt. This type of covenant is known as an incurrence covenant rather than a maintenance covenant, because it does not need to be maintained but is only triggered if further debt is incurred. Yet we already know that a highly leveraged capital structure carries with it an increased risk of default; that lenders are concerned that in the period after a business experiences

\footnotetext{
${ }^{14}$ Mike Wright, Tomas Simons, Louise Scholes and Luc Renneboog, 'Leveraged Buyouts in the UK and Continental Europe: Retrospect and Prospect' July 2006 ECGI - Finance Working Paper No. 126/2006; CentER Discussion Paper Series No 2006-70. Available at SSRN: https://ssrn.com/abstract=918121 (last accessed 9 January 2019)

${ }^{15}$ Louise Gullifer and Jennifer Payne, Corporate Finance Law: Principles and Policy ( $2^{\text {nd }}$ ed, Hart Publishing 2015) 765-767

16 ibid 780-781

17 ibid 773
} 
financial distress, but before it meets a legal test of insolvency, directors may engage in risk-shifting behaviour which threatens the lenders' return on default; and that in finance theory maintenance financial covenants reduce the costs associated with these risks. The first question which arises, therefore, is why this phenomenon exists in highly leveraged capital structures at all.

\section{The Covenant-lite Phenomenon}

The covenant-lite phenomenon first appeared in the US in the years immediately before the 2008 financial crisis.18 At that point in time, covenant-lite loans had not become a feature of the English credit markets, and when the financial crisis hit in 2008 they were attributed, anecdotally at least, to the excesses of the pre-crisis era. In this narrative lenders, at best lulled into a false sense of security and at worst actively exploiting an implied government subsidy of the finance industry, lent cavalierly on loose and irresponsible contractual terms.19 Covenant-lite lending made perfect sense in this account, and this author, at least, anticipated that they would be of no more than historical interest for some time. Indeed, they might have been said to be the epitome of pre-crisis excess.

Yet, in the years since the crisis, there has been a resurgence of the covenant-lite phenomenon, largely associated with PE leveraged buyout transactions.20 Moreover, covenant-lite loans are now very much a feature of the LBO landscape in England.21 In light of our analysis in the first part this seems inexplicable. As a result, the finance literature has recently begun to engage with the question of why these types of contract terms have emerged on such a scale in the leveraged loan market after a major financial crisis. One possibility is that the theory of private equity as an asset class reduces the risks associated with default in other ways, so that maintenance financial covenant protection becomes unnecessary. This is important because, if it is right, it may mean that concerns for the implications of covenant-lite lending have been overdone.

\footnotetext{
18 Billett, Elkamhi, Popov and Pungaliya date the introduction of covenant-lite loans as 2005 noting that, 'they rose in popularity with issuance of $\$ 140$ billion in 2007': Billett et al 'Bank Skin in the Game' (n 11 above) 840. See also Billett at al, 862

${ }^{19}$ A.S. Blinder, After the Music Stopped: the Financial Crisis, the Response, and the Work Ahead (Penguin Press 2013) 84-85

${ }^{20}$ Billett, Elkamhi, Popov and Pungaliya 'Bank Skin in the Game' (n 11 above) 840 and 862

${ }^{21}$ See note 4 above and related text
} 
In this vein, it has been suggested that the quality of monitoring of portfolio companies by the private equity sponsor may reduce the monitoring and alarm-sounding function of maintenance financial covenants. 22 In other words, the chances of default are reduced in these transactions because the private equity firm is paying such close attention to its investment. However, other finance literature indicates that private equity firms may actually undertake lower levels of monitoring in highly leveraged deals.23 A related explanation is that the persistence of private equity performance over time reported in some of the finance literature suggests that there is simply less agency risk associated with loans to the private equity industry.24 Yet the performance question is highly contested, and is certainly not homogeneous across the industry.25 A further explanation is that a diversified private equity sponsor, which has raised a substantial fund, has more capacity to inject further equity into a distressed portfolio company which will address its financial difficulties than a listed or family-owned corporate borrower.26 Yet a question arises as to whether the amount of additional equity which the PE firm will be willing to put in will be equal to the problems which the portfolio company is facing, or whether it is just another way of avoiding the inevitable.27 Finally, there is a suggestion in the literature that the alignment of interests between all of the parties involved in a private equity leveraged buyout (which is at the heart of these transactions) motivates the selection of better target companies for acquisition, once again reducing the risk of distress.28 Yet we have already identified the risks of the leveraged capital structure which may arise independently of

\footnotetext{
22 Demiroglu and James, 'Private Equity Reputation' (n 13 above) 307-308, also citing James F Cotter and Sarah W Peck, 'The Structure of Debt and Active Equity Investors: the Case of Buyout Specialists' (2001) 59 Journal of Financial Economics 101

${ }^{23}$ Francesce Cornelli and Oğuzhan Karakaş, 'Corporate Governance of LBOs: The Role of Boards' (2012), 3. Available at SSRN: https://ssrn.com/abstract=1875649 (last accessed 9 November 2018) 24 ibid 308

25 Ludovic Philippou and Neroli Austin, 'PE Outperformance Doesn't Add Up' Top 1000 Funds 29 August 2018

${ }^{26}$ Demiroglu and James 'Private Equity Reputation' (n 13 above) 308

${ }^{27}$ See market commentary on contractual rights for private equity firms to 'cure' covenant breaches where a leveraged loan does contain maintenance financial covenants, for example, GlobalCapital Equity Cure Rights Take Hold For Sponsor Credits 19 January 2007 available at: https://www.globalcapital.com/article/k65f0vftdlvk/equity-cure-rights-take-hold-for-sponsor-credits (last accessed 10 January 2019)

28 ibid 308
} 
the specific characteristics of the target. In any event, there is alternative evidence that competition between private equity sponsors may weaken the quality of targets which are ultimately acquired.29

If the theory of private equity as an asset class is unpromising as a complete explanation for the covenant-lite phenomenon, we might consider whether there are features of private equity firms which might cause them to behave differently in distress reducing the need for maintenance financial covenant protection. A key theoretical foundation for the private equity model is that each fund makes a number of acquisitions, and the private equity sponsor must thus return to the debt markets frequently to raise funds. 30 This might be expected to increase the protection afforded by reputational bonding, in that private equity sponsors must maintain a good relationship with lenders active in the loan markets in order to be able to raise finance for future acquisitions and to ensure healthy relationships in other deals which they may need to renegotiate. There has been some anecdotal suggestion that this may cause private equity sponsors to call lenders to the table for renegotiation in distress even absent a formal, legal obligation to do so.

The difficulty with this analysis is that private equity sponsors must also consider investor concerns across deals and for future deals. The fund which the private equity firm raises to invest is also time limited, normally for around ten years. This means that the private equity firm must also return to the investment community when it needs to raise a new fund.31 We already know that the theory of the agency costs of debt is that directors may undertake risk-shifting behaviour which is not only in their own interests but also in the interests of shareholders. In the same way, the private equity firm is likely to be highly focused on maintaining its equity value in the portfolio company in its own interests and in the interests of its investors. This is particularly likely to be the case because the decision to invest in a private equity firm is generally a personal, rather than an institutional, decision, relying on the talent of the private equity firm to generate impressive internal rates of return

\footnotetext{
${ }^{29}$ Javier Espinova, 'Private Equity: Flood of Cash Triggers Buyout Bubble Fears' Financial Times (London, 23 January 2018)

30 Billett, Elkamhi, Popov and Pungaliya 'Bank Skin in the Game' (n 11 above) 843

${ }^{31}$ Steven Neil Kaplan and Per Stromberg, 'Leveraged Buyouts and Private Equity' June 2008, 5. Available at SSRN: https://ssrn.com/abstract=1194962 (last accessed 9 January 2019)
} 
and to justify the undeniably high fees charged.32 In other words, the ability to raise a future fund might be expected to be more reliant on investment performance than the ability to access the considerably more market-cycle driven debt markets. A further reason to be doubtful is that the finance literature identifies that covenant-lite loans usually command a premium.33 It would seem unlikely that private equity sponsors would be willing to pay this premium unless they saw some benefit from it, and the most likely benefit is increased control and flexibility during periods of financial distress, avoiding the need to enter into debt restructurings which may target the equity investment, or costly controls on activities such as debt reductions, non-core sales, increased loan pricing and the like. 34

An alternative possibility is that covenant-lite leveraged loans benefit from the spill-over effects of maintenance financial covenant protection in other parts of the capital structure. Leveraged lending usually implicates a relatively complex capital structure. The finance package will typically include a revolving credit facility which can be drawn down, repaid and re-borrowed over its life and which is used for working capital purposes, and revolving credit is normally associated with maintenance financial covenants. However, in a covenant-lite package the revolving credit facility lenders increasingly rely on a single 'springing' leverage ratio which only comes into effect if the revolving credit facility is drawn above a certain percentage. 35 Moreover, the size of the revolving

\footnotetext{
32 Ludovic Philippou, 'Investing in Private Equity Funds: A Survey' 6-7 available at: https://ssrn.com/abstract=980243 (last accessed 12 November 2018)

${ }^{33}$ Billett, Elkamhi, Popov and Pungaliya 'Bank Skin in the Game' (n 11 above) 865-867

${ }^{34} \mathrm{It}$ should be noted that the claim is that the theory is unconvincing as a complete explanation, and that to the extent it does have explanatory power it may explain why the lenders are content to rely on covenant-lite terms but does not necessarily mean that no other borrower or economy-wide concerns arise. For example, it is possible that increased negotiating costs might change the assessment of agency costs for the lenders. In their original work, Jensen and Meckling identified that lenders would take steps to protect themselves if the costs of negotiating and monitoring the contractual protections, together with the cost of the residual risk of adverse directorial action, were less in aggregate than the costs associated with the debt without protection. It may be that because private equity firms do frequently access the debt markets, and are highly expert in leveraged loan financing, the cost of negotiating maintenance financial covenant protection would be higher. At the same time, whilst we were sceptical about the extent to which the theoretical attractions of private equity as a class contributed to debt negotiation, it may nonetheless make some private equity sponsors an attractive proposition, increasing competition among lenders for the loan leading to the loosening of contractual terms including covenant protection. And the increased credit spread may be attractive in a generally low interest rate environment. It seems unlikely that these factors can explain all covenant-lite lending, but they may explain some of it, but strictly from the lenders' assessment of their risk. As we shall see, this may still leave other borrower level and economy-wide level concerns.

${ }^{35}$ Latham \& Watkins, 'Key Issues in Leveraged Lending' (2015) Private Debt Investor 29
} 
credit facility is typically small when compared with the rest of the financing, and generally wellcovered by security, so that the revolving credit facility lenders may feel suitably relaxed about the coverage for their part of the capital structure to sit back and wait to watch the situation unfold.36 In this context it is important to note that typically the covenant-lite loan agreement will provide that it only defaults (entitling the lenders to take action, including stopping further drawdowns or demanding immediate repayment) if the revolving credit facility is accelerated and after a grace period has elapsed.37 For all of these reasons, the spill-over protection from other parts of the capital structure would seem to be slim.

A more fundamental explanation for the rise of the covenant-lite phenomenon centres on the shift from hold to maturity loan markets to actively traded loans. This account starts in, but is not limited to, securitisation. Before the financial crisis vehicles were established, known as collateralised loan obligations (CLOs), to buy packages of loans and issue securities against them. Far from disappearing from the scene after the financial crisis, CLOs have emerged as an even greater force in financial markets in recent years.38 As Rajan, Seru and Vig put it, the significance of the CLO is that it increases the "distance between the originator of the loan, and the party that bears the default risk'.39 In other words, when the bank or other lender negotiates the original loan agreement, they do so in the knowledge that they will not be holding the loan and taking the risk of default, but will be selling it on to a buyer. Of course, this raises the question as to why the buyer is willing to buy. Ayotte and Bolton put the answer succinctly as 'reducing the contract reading costs of potential buyers' .40 The core insight is that, in a rapidly trading market, buyers do not have the time or the resources to diligence the detailed contractual terms of each individual loan agreement. By

\footnotetext{
${ }^{36}$ Demiroglu and James 'Private Equity Reputation' (n 13 above) 311

37 DebtExplained, 'Leveraged Loan Covenants: A Spring in the Tail' available at: https://www.debtexplained.com/explore/insights/the-chairmans-view-covenants-with-a-spring-in-the-tail/ (last accessed 8 November 2011)

38 Victoria Ivashina and Zheng Sun, 'Institutional Demand Pressure and the Cost of Corporate Loans' (2011) 99 Journal of Financial Economics 500, 502

39 Uday Rajan, Amit Seru and Vikrant Vig, 'Statistical Default Models and Incentives' (2010) 100 American Economic Review 506, 506

${ }^{40}$ Kenneth Ayotte and Patrick Bolton, 'Covenant Lite Lending, Liquidity and Standardization of Financial Contracts' in Kenneth Ayotte and Henry E Smith (eds) Research Handbook in the Economics of Property Law (Edward Elgar 2011), 174
} 
standardising the terms and reducing borrower-specific terms, loans become easier to package and to sell. At the same time, the CLO holds a large and diversified portfolio of loans only some of which might be expected to default. It is here that the explanation expands beyond the securitisation analysis.

Whilst CLOs have undoubtedly increased in importance, they are not the only type of institutional lender to have entered the loan market. Indeed, the change in character of the loan market from a hold-to-maturity market to a trading market has opened it up to all sorts of institutional lender. Thus hedge funds, mutual funds, pension funds and insurance companies have all entered the loan market,41 and more recently private equity firms have become significant direct lenders in their own right.42 The benefits of reduced 'contract reading costs' apply equally to these institutions. While a bank in England in the 1970s involved in advancing hold-to-maturity loans would maintain an extensive back office to negotiate and monitor maintenance financial covenants, none of these trading institutions have that type of infrastructure.43 Moreover, a bank in 1970s England would have maintained a close relationship with its long-term borrower client providing it with a wealth of 'soft' information on borrower financial health.44 Indeed, in the 1980s Eugene Fama explained that one of the things which was 'different about banks' was their reduced monitoring costs when compared with other types of lenders, suggesting that this was why other types of financial intermediaries did not enter the loan market.45 Thus the shift from a hold-to-maturity loan market to a trading market and, simultaneously, the shift from bank lenders to institutional lenders probably does most to account for the covenant-lite phenomenon. 46

\footnotetext{
${ }^{41}$ Rajan, Senu and Vig 'Default Models' (n 39 above) 500-501

42 Paul Weiss Discusses New Trends in Private Equity Investment available at: clsbluesky.law.columbia.edu/2018/10/25/paul-weiss-discusses-new-trends-in-private-equity-transactions/ (last accessed 8 November 2018)

43 Tom Cox, Damian Malone and Mark Sinjakli, 'Investing in Distressed Debt in Europe: An Overview' in Ignacio Buil Aldana (ed) Investing in Distressed Debt in Europe (Globe Law and Business 2016), 18

${ }^{44}$ Margaret Ackrill and Leslie Hannah, Barclays: The Business of Banking 1690-1996 (CUP 2001) 225-226

45 Eugene F Fama, 'What's Different About Banks?' (1985) 15 Journal of Monetary Economics 29, 37-38

${ }^{46}$ For a detailed analysis on the relationship between a secondary market for loans and monitoring incentives see Amar Gande and Anthony Saunders, 'Are Banks Still Special When There is a Secondary Market for Loans?' (2012) 67(5) The Journal of Finance 1649
} 
There is evidence of this in the finance literature which shows a relationship between significant institutional demand for loans and covenant-lite terms.47 It also helps to explain why the covenant-lite loan is accompanied by other significant changes which also loosen loan terms: the rise of the so-called Term Loan B designed for institutional lenders with regular interest payments and a bullet repayment;48 the re-emergence of second lien loans ranking behind the term loans but ahead of more deeply subordinated debt; 49 and the rise of payment-in-kind or PIK features in which interest is capitalised as part of the outstanding principal amount of the debt rather than paid in cash.50 Overall, scholars have noted that the loan markets (which have traditionally enjoyed maintenance financial covenant protection) and the bond markets (which have traditionally relied on incurrence covenants) are coming closer together, so that the shift in covenant terms becomes part of a wider phenomenon.51 In this context it is worth making one final point. High yield bonds also adopt incurrence, rather than maintenance, covenants.52 A key reason why these bonds only enjoy incurrence covenants is because the bonds are typically widely held, making them costly to renegotiate in the event of a covenant breach. The careful reader will observe that the same environment is now visible in the loan market.

\section{The Regulatory Response}

Our account thus far has suggested that, once we explore the factors which have led to the rise of covenant-lite leveraged loans, we have reason to believe that those factors do not, in and of themselves, solve the risks which maintenance financial covenants are intended to address. This leads us to the question of the appropriate regulatory response to covenant-lite leveraged loans. Our account has revealed the emergence of an active secondary market for loan debt, and in general there are significant benefits to this liquidity. First, it introduces a new management tool for banks who are

\footnotetext{
47 Billett, Elkamhi, Popov and Pungalyia 'Bank Skin in the Game' ( $\mathrm{n} 11$ above) 842

48 Billett, Elkamhi, Popov and Pungalyia 'Bank Skin in the Game' ( $n 11$ above) 860

49 Ivashina and Sun 'Institutional Demand Pressure' (n 38 above) 508; Demiroglu and James 'Private Equity Reputation' (n 13) 307

50 Demiroglu and James 'Private Equity Reputation' (n 13 above) 307

${ }^{51}$ Elisabeth de Fontenay, 'Do the Securities Laws Matter? The Rise of the Leveraged Loan Market' (2014) 39 Journal of Corporation Law 725

52 NortonRoseFulbright, Accessing Debt Capital Markets - High Yield Bonds available at: http://www.nortonrosefulbright.com/knowledge/publications/51946/accessing-the-debt-capital-marketshigh-yield-bonds (last accessed 9 January 2019)
} 
able regularly to adjust their loan portfolio.53 Secondly, the availability of a deep, secondary market for loan debt is likely to increase the amount of capital available for firms to borrow in the market.54 Thirdly, the availability of capital and competition for loan mandates may reduce the cost of capital.55 And finally, the ability to sell the loans of a distressed borrower may enable those who are no longer willing to support the borrower to trade out, and those who see an opportunity to trade in, increasing the prospects of a successful restructuring. 56 It therefore seems that we would not want to intervene in a way which caused the secondary loan market to cease to operate effectively.

At the same time, we are concerned that the covenant-lite phenomenon will fail to limit excessive borrowing, and will cause borrowing firms to continue to hold creditors at bay long after they should have begun a restructuring process. The first concern is that if too many of these loans become concentrated in a lender's portfolio, they may all be vulnerable to the same sorts of economic shock, and the lender will not able to absorb the losses. Perhaps not surprisingly in the post-financial crisis era, authorities have tended to focus on the risks to the banking sector. This is, after all, the part of the financial system which is widely acknowledged to be of systemic importance and is the part of the system which was bailed out by governments around the world using taxpayers' money. Thus the European Central Bank (ECB) has focused on ensuring that highly leveraged loans do not become consolidated in the banking sector. Whilst the regulatory intervention is focused on leveraged loans, as covenant-lite lending is concentrated in the leveraged sector of the loan market it is likely to be swept up by association. Thus the ECB has published leveraged loan guidance suggesting limits on leveraged lending, and enhanced monitoring and reporting.57 However, this guidance only applies to

\footnotetext{
53 Gande and Saunders 'Are Banks Still Special' (n 46 above) 1650

54 ibid 1651 citing Steven Drucker and Manju Puri, 'On Loan Sales, Loan Contracting and Lending Relationships' (2009) 22 Review of Financial Studies 2835; Ivashina and Sun 'Institutional Demand Pressure' (n 38 above) 510 55 ibid 1651 also citing Christine A Parlour and Andrew Winton, 'Laying Off Credit Risk: Loan Sales Versus Credit Default Swaps' (2013) 107(1) Journal of Financial Economics 25 and Anurag Gupta, Ajai K Singh and Allan A Zebedee, 'Liquidity in the Pricing of Syndicated Loans' (2008) 11 Journal of Financial Markets 339 ${ }^{56}$ Sarah Paterson, 'Rethinking Corporate Bankruptcy Theory in the Twenty-first Century' (2016) 36(4) OJLS 697. 710

${ }^{57}$ European Central Bank, Guidance on Leveraged Loan Transactions 2017
} 
regulated financial institutions and, as we have seen, this is where most of the institutions driving the covenant-lite phenomenon sit.58

It may very well be that this regulatory intervention is sufficient to prevent systemic risk in the finance system. Whilst the picture is murky, because the linkages between the banks within the regulatory net and the institutions which sit outside it remain opaque, it may very well be that the collapse of even a large number of institutional lenders would pose no or little systemic risk for the financial system.59 It is also possible that institutional lenders with an actively traded, widely diversified (or appropriately hedged) portfolio may be able to absorb any increased losses arising on default of covenant-lite leveraged loans. But even if we do not consider that there are systemic risks to the financial system, there are nonetheless public policy considerations. First, even if institutional lenders can absorb increased losses, other creditors at the borrower level will not necessarily be able to do so, notably employees and small trade creditors. The English corporate insolvency system has traditionally been a particularly friendly environment for large, secured lenders. In part, this is because authorities historically benefitted from co-operation with the principal lending banks in the UK, and other creditors benefitted from the negotiation and monitoring function of these lending banks in the corporate loan market.60 Once these monitoring and negotiation functions fall away, the spill-over benefits for employees and smaller trade creditors at the borrower level also fall away.61 Insofar as trade creditors are concerned, small businesses make up the bulk of the English economy so that there may very well be system wide effects from failure of a large number of small businesses: the so-called ripple effect. At the same time, if highly leveraged covenant-lite loans turn out to be heavily pro-cyclical, large numbers of jobs could potentially be at risk if the market turns. There are reasons, then, to be serious about addressing the covenant-lite phenomenon even if the covenant-lite loans are not concentrated in systemically important financial institutions.

\section{The Corporate Insolvency Law Toolbox}

\footnotetext{
${ }^{58}$ Billett, Elkamhi, Popov and Pungaliya 'Bank Skin in the Game' (n 11 above) 858, 862-865

59 ibid 859

60 John Armour and Sandra Frisby, 'Rethinking Receivership' (2001) 21(1) OJLS 73

${ }^{61}$ Gande and Saunders 'Are Banks Still Special' (n 46 above) 1651
} 
It is here that corporate insolvency law takes to the stage. After the financial crisis a significant number of maintenance financial covenants in highly leveraged loans were breached.62 Once a financial covenant had been triggered, directors had little choice but to engage with the lending group. First, the common law duties of directors to creditors in the vicinity of insolvency were engaged.63 On a maintenance financial covenant breach the lenders' right to accelerate the loan and demand immediate repayment was triggered. At this point, unless the loan could be refinanced in the credit markets (unlikely after a financial covenant breach), it would be a straightforward affair for the lenders to demand repayment and render the finance holding company borrower cash flow insolvent. Secondly, the wrongful trading regime also came into play, so that in order to continue to trade without risk of personal liability the directors would be required to conclude that there was a 'reasonable prospect of avoiding insolvent liquidation' 64 - unlikely to be the case without engaging with the lenders of the defaulted loan debt. As anticipated, the lenders did not actually accelerate the debt, but the legal regime engaged with the maintenance financial covenants to force the directors to the table.

This was further reinforced by the effect of accounting standards. Both Financial Reporting Standard 102 and International Accounting Standard 1 require that accounts contain a going concern statement, or must be prepared on a liquidation basis. In making the going concern statement, an auditor is required to look forward for at least the next 12 months. This means that where a financial covenant breach is forecast in the next 12 months, the auditor will require some reassurance as to going concern. Where there is a matter which casts a significant doubt about the company's ability to continue as a going concern, an emphasis of matter statement must made in the accounts, 65 essentially highlighting the issue which casts doubt over going concern and explaining how the directors propose to deal with it. In the context of a forecast maintenance financial covenant breach, this most

\footnotetext{
${ }^{62}$ Attila Takacs, European Restructuring Report: Default, Restructuring and Recoveries in 2008-2010 Debtwire Europe 2010. Available at: http://www.debtwire.com/pdf/Restructuring Report 2008 2010.pdf (last accessed 9 January 2019)

63 Companies Act 2006, s 172(3)

64 Insolvency Act 1986, s 214

65 Companies Act 2006, s 495(4)
} 
commonly takes the form of a statement that the directors are in constructive discussion with the lenders.66 The overall effect of these accounting requirements is often to bring forward the date at which the directors are required to sit down with lenders and begin restructuring negotiations.

Thus, in the decade since the financial crisis, breach of maintenance financial covenants, common and statutory law duties of directors of English companies, and relevant accounting standards have operated to force directors and lenders of distressed leveraged loans to come to the table to begin negotiations. As restructuring negotiations have started relatively early, the financial liabilities have been sufficient to absorb the loss, and the restructuring has been contained in the group finance holding company which borrowed the debt, enabling a business-as-usual message to be conveyed to customers and suppliers of the operating subsidiaries and, if all goes well, minimising the value-destructive consequences of insolvency of the group. Crucially, because the restructuring negotiations were triggered by the early warning system of the maintenance financial covenant, although the group holding company may have been struggling with reduced cash flow to meet debt service obligations, the operating companies generally had sufficient liquidity to stretch to meet dayto-day operational liabilities whilst the financial restructuring negotiations continued at the holding company level.

The English scheme of arrangement procedure, 67 which has been on the statute books since the end of the nineteenth century when it was developed for restructuring the nation's railways, has proved particularly well-adapted as an implementation tool for these financial restructurings. 68

\footnotetext{
${ }^{66}$ Barry Elliott and Jamie Elliott, Financial Accounting and Reporting (18 ${ }^{\text {th }}$ ed, Pearson 2017) 136

${ }^{67}$ Companies Act 2006, Part 26 s 895-899

${ }^{68}$ An early hearing is held at which the court essentially confirms the way in which the finance holding company has organised voting on the scheme, minimising the risk of disruption later (Re Telewest Communications plc (No 1) [2004] EWHC 924 (Ch), [2004] BCC 342; Re Sovereign Marine [2006] EWHC 1335 (Ch), [2006] WLUK 136); the scheme is a Companies Act procedure so that some of the negative connotations of an insolvency procedure for non-financial creditors of the operating subsidiaries concerned about what is happening at the holding company level can be avoided; the scheme procedure is relatively rapid (about six weeks in total); court involvement is relatively limited and the court is unlikely to interfere if the majority of finance creditors support the scheme so that execution risk is minimised (Re English, Scottish and Australian Chartered Bank [1893] 3 Ch 385, [1893] 7 WLUK 52); and finally (and significantly) guarantee obligations of the operating subsidiaries for the finance company's financial liabilities can be released in the finance holding company scheme of arrangement, so that it is not necessary to place the operating subsidiaries into any kind of process at all (In re Lehman Brothers International (Europe)(in administration)(No 2) [2009] EWCA Civ 1161; [2010] Bus L R 489)
} 
However, as we have seen, covenant-lite leveraged loans lack the early warning mechanisms which have shaped the way in which these financial restructurings have proceeded. Crucially, they may have the result that the lenders and the borrower come to the table much later. At best, this increases the risk that the level of financial distress will be deeper, so that a more radical financial restructuring will be needed than has typically been the case in the decade since the financial crisis. At worst, it increases the risk that the problems will have spread from financial distress, in which the finance company is struggling to service the loans which it has borrowed, to economic distress in which the operating subsidiaries are struggling to meet their operating liabilities.69 As we shall see, if this is right then additional corporate insolvency law tools may be needed to reduce losses on default, which cannot be provided by the scheme of arrangement and may not be available anywhere else in the existing English corporate insolvency law toolbox.

\section{A Moratorium Protection}

The first tool which has not been significant in the restructurings of the last decade, but which may be needed as a result of the growth in covenant-lite lending, is moratorium protection. There are two principal reasons why this has not been a significant concern in the financial restructurings of the last cycle. First, in part as a result of loose monetary policy conditions, there has been an active market for the buying and selling of loans to distressed borrowers, so that those who are not willing to support the debt restructuring have generally been able to trade out, and those who saw an opportunity to support a restructuring have traded in. Secondly, leveraged loans are generally documented in England and Wales using negotiated forms of documents provided by the Loan Market Association (LMA). The LMA inter-creditor agreement sets out detailed restrictions on acceleration and enforcement action by junior creditors and, even after the end of the contractual standstill period, enables senior creditors to take over the conduct of the enforcement process. 70 In general, this has meant that those with an incentive to take aggressive action have had limited ability to pursue it,

\footnotetext{
${ }^{69}$ For the distinction between financial distress and economic distress see Douglas G Baird, 'Bankruptcy's Uncontested Axioms' (1998) 108(3) The Yale Law Journal 573, 580-581

70 These restrictions include a standstill for (usually) 90 days for a payment default, 120 days after a financial covenant breach and 120 or 150 days after other defaults
} 
whilst those with an incentive to pursue a more consensual restructuring procedure have remained in control.

The position is, however, different if financial distress has spread to economic distress in the operating group. The reason why moratorium protection may be more important in this situation is that trade creditors have a wider range of options available to them to respond to distress, and are not bound by the detailed inter-creditor arrangements which govern the financial creditors. For example, trade creditors may lodge winding up petitions in an effort to incentivise the company to repay them, may refuse further supply until their outstanding liabilities have been paid and may amend their payment terms reducing the number of days between supply and payment causing severe cash flow problems for the debtor. English corporate insolvency law does currently offer two, different, statutory moratoria which may be applicable in a restructuring, but as we shall see neither of them is particularly well adapted to a financial and operational restructuring of a large company.

The company voluntary arrangement procedure provides optional moratorium protection, 71 but only if the company satisfies the conditions for a small company which is unlikely to be the case for the sorts of portfolio private equity borrowers with which this article is concerned.72 Moreover, in a recent report for R3 (the trade association for insolvency practitioners in the UK) and the Institute of Chartered Accountants of England and Wales, Walton, Umfreville and Jacobs suggest that companies are not making great use of the moratorium in company voluntary arrangements even where they are eligible for it.73 The report goes on to note that some of the companies which would be eligible to seek moratorium protection have combined the company voluntary arrangement with an administration, in order to gain the alternative moratorium protection which an English law

\footnotetext{
71 Insolvency Act 1986, Sch A1

72 The relevant conditions are set out in the Companies Act 2006, s 382(3) and subject to the exceptions set out in the Insolvency Act 1986, Sch A1, paras 2,3 and 4

73 Peter Walton, Chris Umfreville and Lézelle Jacobs, Company Voluntary Arrangements: Evaluating Success and Failure available at:

https://www.r3.org.uk/media/documents/policy/policy_papers/corporate insolvency/R3_ICAEW CVA_Repor t May 2018.pdf (last accessed 7 January 2019). This may be because the potential liability of the insolvency practitioner in proposing the Schedule A1 moratorium, versus the likely scale of remuneration for the role, has made insolvency practitioners reluctant to suggest moratorium protection is sought.
} 
administration provides.74 The administration moratorium would prevent some of the trade creditor action which we identified as a concern in the restructuring of an operating company. 75 However, current authority provides that the administration moratorium does not prevent the creditor from exercising certain 'self-help' remedies, such as exercising rights to terminate contracts for the administration of the debtor counterparty or demanding shorter payment terms as a condition of continued supply.76 This brings us to the second set of corporate insolvency tools which may be needed to achieve a restructuring in an operating, as opposed to a finance, company: tools which shift some bargaining power to the distressed debtor to enable the debtor to keep operating arrangements on foot without devastating cash flow consequences while the restructuring is being negotiated.

\section{B. Tools to Assist the Debtor in Keeping and Terminating Contracts}

Perhaps the leading example of a tool to assist the debtor in keeping or terminating contracts is the ban on ipso facto clauses in US Chapter 11. The US Bankruptcy Code expressly prohibits a counterparty from terminating or modifying a contract at any time before the closing of the Chapter 11 case arising as a result of the insolvency or financial condition of the debtor, the commencement of the Chapter 11 case or the appointment of a trustee or custodian in the Chapter 11 case. 77 However, the tools in Chapter 11 go beyond a simple ipso facto ban. Indeed, Chapter 11 sets out detailed mechanisms which enable the debtor company either to assume a contract or terminate it and, pending a decision on assumption and termination, prevent the counterparty from simply automatically stopping performance. 78

\footnotetext{
74 Insolvency Act 1986, Sch B1, para 43

75 For example, the trade creditor would be prohibited from lodging a winding up petition against the company, or commencing execution proceedings against the company's assets, without the consent of the administrator or the consent of the court - Insolvency Act 1986, Sch B1, para 43(6)

${ }^{76}$ Re Olympia \& York Canary Wharf Ltd American Express Europe Ltd \& Ors v Adamson \& Ors [1927] 7 WLUK 374; [1993] BCC 154

7711 U.S.C $\S 365$ (e)

7811 U.S.C. $\S 365$ (a) - (d). In order to assume a contract, the debtor must, amongst other things, pay any outstanding liabilities from the period before the debtor filed for Chapter 11 protection.
} 
This suite of tools is obviously helpful to a debtor seeking to restructure its operations, but it also clearly intervenes significantly in the bargain struck between the debtor and the creditors before the Chapter 11 filing. Notably, it may create significant cash flow problems for the non-insolvent counterparty who may find itself obliged to continue to fund its own obligations in order to be in a position to be able to continue to supply the Chapter 11 debtor, whilst at best the Chapter 11 debtor has not paid for the pre-filing supply and, at worst, the counterparty is concerned about payment for post-petition supply. Furthermore, it may prevent the counterparty from renegotiating its contract whilst that may be an entirely legitimate objective where insolvency causes the counterparty to view the risk which it is taking differently from the way in which it viewed that risk when the original bargain was struck. As a result, while these corporate bankruptcy tools are undoubtedly helpful for an operational restructuring, they remain controversial.

The rules of the market place may mitigate some of these controversies. Although it is the case that the counterparty is legally prevented from terminating or modifying its contract while it is under an obligation to continue to supply, this may not reflect the commercial reality. The counterparty may find myriad excuses to avoid supply.79 This reality has led to so-called critical vendor programmes in Chapter 11, in which the bankruptcy court permits the debtor to pay certain 'critical vendors' their pre-filing liabilities in full in order to be assured of seamless, continued supply.80 Whilst this relatively clearly undermines the legislative scheme of the US Bankruptcy Code, it is a pragmatic solution to the practical realities of the market place. Secondly, a counterparty who is unhappy with the assumption of its contract in Chapter 11 is likely to look for ways to end its relationship with the debtor after the termination of the Chapter 11 case. In other words, while the detailed mechanics serve a purpose in moving bargaining power to the debtor in the Chapter 11 case, they do not undermine the practical need to strike a deal with the creditor. Thus, if mechanisms are built into corporate insolvency law to shift bargaining power to the debtor in order to facilitate an

\footnotetext{
79 Ranging from a broken down delivery van, to problems with its own deliveries, to issues in the stock room, to asserting that it will face insolvency itself if it continues to perform.

${ }^{80}$ Mark J. Roe and Frederick Tung, 'Breaking Bankruptcy Priority: How Rent-Seeking Upends the Creditors' Bargain' 2013 99(6) Virginia Law Review
} 
operational, as well as a financial, restructuring, they may need to be bolstered by mechanisms which enable the debtor to pay critical suppliers in order to deal with the practical problems of keeping a business in restructuring together. This also indicates the scale of the renegotiation exercise if covenant-lite terms mean that a restructuring implicates both financial and operational liabilities.

\section{An Honest Broker}

This leads us to the third corporate bankruptcy tool which is arguably less important in a restructuring of financial liabilities confined within a finance company: the presence of what we might call an 'honest broker'. In a financial restructuring in a finance company only sophisticated financial creditors are implicated who had the full range of investment opportunities available to them, are subject to detailed contracts allocating control rights in distress, and benefit from extensive professional advice. In this case, it is defensible that court involvement is relatively limited and that the court is unlikely to interfere if a sufficient majority support the restructuring. Very different concerns arise, however, in restructuring an operating company where employees and a range of creditors with different levels of sophistication and bargaining power may be implicated. In a US Chapter 11 proceeding, the court has a central role in reviewing and approving almost every step of the process, but this has cost implications. In England's principal corporate insolvency procedure, administration, there is a sophisticated division of labour between the administrator (who must be a regulated insolvency practitioner) 81 and the court. Very broadly, the administrator is responsible for the commercial decisions in the case and the court will determine legal questions.82 Yet displacement of management may give rise to concerns in a restructuring where the plan is ultimately to hand the business back to the directors.

Whilst the two, principal, models have been what we might call debtor-in-possession procedures with court oversight, or management displacement by an insolvency practitioner with limited court oversight, more nuanced versions are possible. The company voluntary arrangement

\footnotetext{
81 Insolvency Act 1986, Sch B1, para 6

${ }^{82}$ Re Lehman Bros Int. (Europe) (in Administration) Four Private Equity Investment Funds v Lomas [2008] EWHC 2869 (Ch), [2008] 11 WLUK 598
} 
already illustrates a middle way. In a company voluntary arrangement, an insolvency practitioner is appointed who is known as the nominee (before the company voluntary arrangement is approved) 83 and the supervisor (after approval).84 The nominee/supervisor has particular functions, prescribed both in statute and in the company voluntary arrangement itself, and is not seen as displacing the directors. At the same time, the insolvency practitioner is capable of fulfilling an 'honest broker' role between the negotiating creditors. Similarly, while administration is regarded practically as a management displacing procedure, in fact the directors remain in office unless they are removed by the administrator, 85 and it is possible for the administrator to consent to leave powers in their hands during the course of the case.86 Indeed, in 2001, at the court application for administration of Railtrack plc (then the existing UK rail infrastructure owner) a 'Day One Order' was sought and obtained pursuant to which day-to-day management powers were left with the directors. This approach was also adopted in the administration of Metronet, operator of part of London Underground's rail network.87 Thus, more complex models than a court-heavy or management displacing procedure are possible, which may nonetheless provide the necessary level of protection which it is suggested may be needed if covenant-lite lending implicates a wider group of creditors.

\section{Cram Down and Priority Rules}

Thus far, we have concentrated on corporate bankruptcy tools which may be needed for the next restructuring cycle because, it is argued, covenant-lite lending increases the prospect that the parties come to the negotiating table late, with the result that financial distress in the finance company has spread to economic distress in the operating subsidiaries. Yet it is possible that, even though the parties come to the table late as a result of the covenant-lite terms (so that the financial distress is more severe than it might have been if financial maintenance covenants had triggered discussions), it may still be possible to undertake a restructuring limited to financial liabilities. As a result, the final

\footnotetext{
83 Insolvency Act 1986, s 1(2)

84 Insolvency Act 1986, s 7(2)

85 Insolvency Act 1986, Sch B1, para 61

${ }^{86}$ This is because the Insolvency Act 1986, Sch B1, para 64 provides that, 'an officer of a company in administration may not exercise a management power without the consent of the administrator' ${ }^{87}$ Rodrigo Olivares-Caminal, Alan Kornberg, Sarah Paterson, John Douglas, Randall Guynn and Dalvinder Singh, Debt Restructuring (2 ${ }^{\text {nd }}$ ed, OUP 2016) 205-206
} 
two sets of tools which may be needed as a result of the rise in covenant-lite lending apply both to a deeper restructuring of the financial liabilities alone, and a restructuring of both financial and operational liabilities at the finance holding company and operating subsidiary levels. The first of these two sets of tools is a 'cram down' power with priority rights. As a matter of procedural efficiency, creditors vote in a single class in a company voluntary arrangement.88 However, this does not allow the company to ignore completely different rights which creditors have under the arrangement.89 In a scheme of arrangement creditors are divided into classes for the purposes of voting, and a majority of $75 \%$ by value and a majority in number of those voting is needed in each class for the scheme to be approved.90 However, in contrast with US Chapter 11, English law currently lacks a restructuring procedure which enables a restructuring to be imposed on an entire class of dissenting creditors.

To date, English lawyers have developed a workaround for this in which the finance holding company is placed into administration and the shares in the operating subsidiaries are sold to a newly formed company, owned only by those lenders which are to be offered consideration in the restructuring.91 This is a cumbersome process. In the period since the financial crisis it has not been implemented frequently, because all of the factors we have already examined have meant that there has generally been enough value to offer something to each class of financial creditor in the restructuring. Once again, it is a controlling principle of this article that covenant-lite terms make it more likely that restructuring negotiations start later than has typically been the case after the financial crisis, and that this means it is more likely that financial distress in the finance holding company will have spread to economic distress in the operating subsidiaries. The workaround is poorly adapted to this situation. Moreover, even where this is not the case and the problem is still confined to one of financial distress, it may be more likely that there will be insufficient value remaining to offer

\footnotetext{
88 Insolvency Rules 201615.34

89 Prudential Assurance Co Ltd v PRG Powerhouse Ltd and others [2007] EWHC 1002, [2007] Bus. L.R. 1771. It should also be noted that a company voluntary arrangement cannot compromise secured or preferential creditors without their consent (Insolvency Act 1986, s 4(3)). This means that it is of limited utility in so far as leveraged loans are concerned, as these are usually secured in the English market.

90 Insolvency Act 1986, s 899

91 Olivares-Caminal et al, Debt Restructuring (n 87 above) 261-266
} 
anything to an entire class of financial creditors, so that the workaround needs to be employed more regularly. It is suggested here that the workaround is poorly adapted as a regular solution, given that it is a clever adaptation of a procedure built on foundations designed for a different purpose.

US Chapter 11 does contain a power for the court to 'cram down' a restructuring plan proposal on an entire class of dissenting creditor.92 However, the court plays a significant role in confirming such a plan, particularly in the area of valuation and the so-called absolute priority rule. Insofar as valuation is concerned, a complex process is undertaken in which each class typically appoints its own valuation expert to value the business after the restructuring using traditional valuation mechanisms. However, significant dispute is likely, given that valuation experts can err on the side of valuation ranges which best support their clients' objectives.93 At present, because the workaround which is used in England engages an administration sale of the shares in the operating group, the valuation which is implicated is the value of the operating group in current market conditions. The US has historically eschewed this approach, for fear that restructurings are most likely to take place when the market is generally distressed, so that using current market prices as a basis for valuation may produce values below what we might call the 'intrinsic' or 'fundamental' value.94 Thus there is a significant debate about the 'right' approach.

It may very well be that the answer to this question depends, once again, on whether the restructuring is confined to finance liabilities, or whether it implicates operational liabilities. Where the restructuring is confined to financial liabilities, provided the way in which the question will be approached is clear to the financial creditors when they enter into the loan, they ought to be able to price for the risk. Furthermore, as we have already seen, it is likely that the financial creditors will enter into detailed contracts to govern their relationship and they may build additional protections into those contracts if they are able to negotiate for them. All of this argues in favour of a straightforward approach. However, different considerations may arise if financial distress has morphed into

\footnotetext{
92 U.S.C § 1129(b)

93 Olivares-Caminal et al, Debt Restructuring (n 87 above) 267

94 Ibid 266-272
} 
economic distress in the operating subsidiaries, implicating both financial and operational liabilities. This is, first, because the trade creditors may have had less bargaining power to adjust their risk before corporate insolvency and, secondly, because they will not be party to the same sort of contract regulating the rights of creditors inter se as the financial creditors. Thus, if covenant-lite lending does increase the risk that a restructuring will not be confined to financial liabilities in the finance holding company, difficult questions arise in developing cram down tools in corporate insolvency for the full range of cases which may arise. Specifically, there is both the question of working out the approach which will be adopted, and the difficulty of who has the expertise to oversee its application.

A similar difficulty arises with statutory priority rules. In Chapter 11, the principal priority rule is the so-called absolute priority rule which essentially requires that no junior creditor is paid until more senior creditors are paid in full and, as a corollary, that no creditor class should receive more than it is owed.95 This is relatively uncontroversial in a financial restructuring where the intercreditor agreement already regulates the ranking of the various classes of debt. However, it raises more difficult issues in a restructuring which also implicates operational liabilities. This is because, in a mixed financial and operational restructuring, it may be necessary to pay some trade creditors a greater proportion of their claims than senior financial creditors in order for the business to go on to trade successfully once it has emerged from the restructuring negotiation.96 Once again, this may mean that a more flexible approach is needed in a restructuring implicating operating liabilities of operating subsidiaries than one which is confined to the financial liabilities of the finance holding company. And once again this gives rise to two, difficult questions. First, the question arises as to how the detail of the tests for when to apply the priority rules and when to allow derogations will be worked out. Secondly, the question arises as to whether the court will oversee this, or an insolvency practitioner, or some other route adopted.

\footnotetext{
95 U.S.C. § 1129(b)(1). For a more detailed analysis see Olivares-Caminal et al, Debt Restructuring (n 87 above) 171-176

${ }^{96}$ For a recent example of the sort of situation in which this can arise see Rama Douglas, 'Horizontal Gifting Upheld in a Chapter 11 Plan in the Third Circuit' Harvard Bankruptcy Roundtable available at: https://blogs.harvard.edu/bankruptcyroundtable/2018/11/13/horizontal-gifting-upheld-in-chapter-11-plan-inthe-third-circuit/ (last accessed 7 January 2019)
} 
E. Getting Further Finance into the Case

The final corporate bankruptcy tool which has not typically been needed in post-financial crisis restructurings, but which may be needed if the controlling argument of this article proves correct, is the ability to get additional finance into the case during the restructuring. As the majority of postfinancial crisis restructurings of leveraged loan arrangements started at a fairly early point in time as a result of the operation of financial maintenance covenants, although liquidity may have tightened during the restructuring negotiations, there was not generally a pressing need to get additional finance into the company during many of the restructuring negotiations. However, if lenders and borrowers come to the table much later to restructure covenant-lite lending arrangements, then it must be more likely that the company will have an immediate liquidity need, so that it is necessary to get more financing into the group during the restructuring negotiations. Famously, Chapter 11 contains a specific regime to facilitate this.97 It has been argued that administration also contains a mechanism which would facilitate this, but to date it is untested.98

\section{The Corporate Insolvency Law Toolbox and the UK Government Reform Proposals}

As discussed in Part 1, three new corporate insolvency tools are proposed in the UK Government Response to the Insolvency and Corporate Governance consultation. The first tool is a new, standalone 'pre-insolvency' moratorium which could be used while a contractual renegotiation, company voluntary arrangement, scheme of arrangement, or a new restructuring plan (see below) is developed.99 The second tool is a statutory ban on termination clauses as a result of filing for an insolvency or restructuring process.100 And the third tool is the introduction of a new restructuring plan procedure which will facilitate cram down between classes and which could also benefit from the new moratorium.101 We will now take each of these in turn in considering whether they address the

\footnotetext{
97 U.S.C. $\S 361$

98 For the debate see Sarah Paterson, 'Finding Our Way: Secured Transactions and Corporate Bankruptcy Law in America and England' 2018 18(2) Journal of Corporate Law Studies 247, 253-254

99 Government Response (n 5 above) 42-58

100 ibid 58-63

101 ibid 63-74
} 
gaps in the English corporate insolvency law toolbox which we have identified in the context of restructuring covenant-lite leveraged loan borrowers and their groups.

The new moratorium proposal provides for the appointment of a 'monitor' to initiate and supervise the moratorium (currently envisaged to be an insolvency practitioner, but with flexibility for other bodies to propose qualifying mechanisms).102 It contemplates an initial moratorium of 28 days which can be extended by the company for a further 28 days (provided the monitor is content that the qualifying conditions continue to be met and notifies creditors). Extension beyond 56 days will require consent of the creditors (more than 50 per cent by value of each of the secured and unsecured creditors - presumably of those who vote) or, where that is impracticable, consent from the court. Where a statutory procedure such as a scheme of arrangement or company voluntary arrangement has been proposed to creditors the moratorium will automatically extend until creditors accept or reject the proposal.103

As currently envisaged, the moratorium will not be available for companies which are already insolvent. Instead, the qualifying condition will be that the company will become insolvent if action is not taken. 104 This requirement that the company is not unable to pay its debts at the time at which it seeks moratorium protection would appear to pose an immediate challenge where the purpose of the moratorium is to assist companies in a group where distress has reached beyond purely financial distress and has developed into economic distress. Furthermore, the new monitor appears to have significant exposure in the new regime.105 Although the response suggests immunity from claims, 'stemming from erroneous termination provided [the monitor] acted in good faith',106 nothing is said about failure to terminate which would appear to pose bigger risks. The Government Response

\footnotetext{
102 ibid 53

103 ibid 51-52

104 ibid 47

105 ibid 54-55. He must be satisfied that the company meets the financial requirements for entry into the moratorium. Moreover, he is required to satisfy himself that rescue is more likely than not. He must be comfortable that the company will have sufficient funds to carry on business during the moratorium and, as the name would suggest, has an ongoing monitoring role so that he must terminate the moratorium if he considers the company has ceased the meet the qualifying conditions.

106 ibid 55 para 5.68
} 
indicates that the monitor will be an officer of the court, providing some protection, 107 yet there remains the very real risk that any liability exposure is unattractive given the likely scale of fee for the job. The Government Response points to the fact that the monitor will be free to take on other roles in the case, 108 yet the reality is that in many restructuring transactions these additional services are typically provided by the investment banking community. Furthermore, the monitor will be prohibited from taking on a subsequent administration or liquidation appointment for 12 months,109 and, if the restructuring attempt fails, his fees will be subject to challenge, 110 and will rank last out of the expenses of the moratorium which are afforded priority in a subsequent insolvency case.111 For the moment, at least, all of these features would seem to make the new moratorium somewhat unattractive in the situations with which this article is concerned.

The second new corporate insolvency tool is the proposal to ban termination clauses as a result of filing for an insolvency or restructuring process.112 We have already argued that there may need to be stronger moratorium protection where covenant-lite lending leads to a restructuring negotiation. However, the detail of the proposal seems to require some further working out. First, the ban appears to apply not only in 'full' procedures, but also to the new pre-insolvency moratorium (discussed above) or the new restructuring plan proposal (discussed below) which, as presently envisaged, can be implemented with no insolvency practitioner involvement and relatively light court supervision.113 This may require further thought given the public policy considerations of an ipso facto ban discussed above. Secondly, the proposal draws no distinction between creditors who are owed outstanding liabilities at the date of filing and creditors who are paid up to date, whilst, as discussed above, the proposal would appear to have very different implications for these two groups. And finally, there is nothing explicit to replicate the assumption and termination technology in Chapter 11, in other words, to shift bargaining power so that not only is the creditor stayed but the

\footnotetext{
107 ibid 55 para 5.72

108 ibid 55 para 5.70

109 ibid 56 para 5.76

110 Ibid 55-56 para 5.73

111 ibid 57 para 5.79

112 ibid 58-63

113 ibid 60 para 5.98
} 
necessary renegotiation can take place. It is possible that other tools in the corporate insolvency toolbox can be adapted and mobilised for this purpose, 114 but the use of the various tools together appears to require further thought.

Finally, the proposals provide for a new restructuring plan proposal which will allow crossclass cram down of a company's restructuring proposals on both secured and unsecured creditors.115 The plan proposal is closely modelled on the existing scheme of arrangement, and would seem to be sufficiently flexible to address both the compromise of financial liabilities and the variation or termination of contracts for the purposes of reshaping the company's operations.116 The only requirement, for the purposes of the scheme, is that there is some element of 'give and take'.117 Accordingly, provided the creditor receives some benefit in the restructuring plan, it would seem possible to undertake a wide range of operational restructurings. At the same time, the flexibility to impose the plan on a dissenting class will remove much of the holdout threat which would otherwise arise. This leads, however, to the question of how the enterprise will be valued for the purposes of allocating the reorganisation proceeds amongst the consenting creditors, and who will oversee the application of the rules.

The Government Response indicates that the debtor will be required to identify the "next best alternative' to the restructuring plan proposal and, provided the restructuring plan provides at least as good a return as that alternative, it will be capable of confirmation. 118 However, this article has argued that although most large company restructurings after the financial crisis have been financial

\footnotetext{
${ }^{114}$ The Insolvency Act 1986 Sch B1 para 66 permits an administrator to make a payment other than in accordance with the normal rules of distribution where 'he thinks it is likely to assist the achievement of the purpose of the administration' and the Insolvency Act 1986 Sch 1 para 13 empowers the administrator to make 'any payment which is necessary or incidental to the performance of this functions'. Administrators can currently use these powers to pay what English lawyers normally call 'ransom creditors', for example in order to secure ongoing supply. An administrator may also be able to use a company voluntary arrangement, scheme of arrangement or the new restructuring plan procedure discussed below to terminate or modify a contract. However, once again, this sort of restructuring has been rare in England and Wales and is, thus, once again untested

${ }^{115}$ Government Response (n 5) 63-74

${ }^{116}$ So that, as noted in note 114 above, there may be some technology which could be used for reshaping contractual obligations, notwithstanding the absence of an express regime for assumption or rejection ${ }^{117}$ Re NFU Development Trust Ltd [1972] 1 WLR 1548, [1973] All E.R. 135; Re Uniq plc [2011] EWCH 749 (Ch), [2011] 3 WLUK 846

118 Government Response (n 5 above) 74 para 5.174
} 
restructurings, there is reason to suspect that the explosion of covenant-lite leveraged lending may lead to a greater need for operational as well as financial restructuring. This implicates many concerns for distributional fairness which do not arise, or which arise to a lesser extent, where a restructuring is between sophisticated financial creditors.119 The Government Response appears to deal with this concern by emphasising that the court will always have discretion as to whether to sanction a plan or not on just and equitable grounds.120 Yet judges have been extremely reluctant to develop what we might call judge-made law in the field of insolvency as it has become increasingly statute-based, confining themselves to what they have identified as the "interstices" left by the legislature.121 This leads to the question of who will oversee confirmation. The Government Response envisages that the restructuring plan is likely to be used as a standalone procedure, but explicitly provides that an administrator would be able to propose a restructuring plan.122 Including some sort of regulated insolvency professional into the process might enable the traditional division of labour between the court and the insolvency practitioner to be retained, whilst observing the need for an 'honest broker' where creditors of different levels of sophistication and bargaining power are implicated. Once again, overall, there would appear to need to be some further thought.

Finally, the Response indicates that the Government, 'has ... decided not to proceed with the rescue finance proposals at this time, but will keep the issue under review'.123 As discussed above, it may be that an administrator is already equipped with powers to facilitate the raising of further finance during the restructuring negotiations. However, as we also noted, the position is currently untested and so it may be that a brave market participant would need to blaze a trail before there was general confidence in the analysis.124 Once again, equipped with a detailed analysis of the

\footnotetext{
119 Sarah Paterson, 'Debt Restructuring and Notions of Fairness' (2017) 80(4) Modern Law Review 600

120 Government Response (n 5 above) 72 para 5.166

${ }^{121}$ Hildyard L.J., 'Mind the Gap: Insolvency, Interstitial Innovation and Implications of Brexit' available at: http://www.ilauk.org/docs/news/insolvency and interstitial innovation final draft 26 september.pdf (last accessed 2 November 2018)

122 Government Response (n 5 above) 66 para 5.132

123 ibid 76 para 5.186

${ }^{124}$ Note 98 above and related text.
} 
implications of covenant-lite lending for the corporate insolvency toolbox we can see that the current proposals require some further thought.

\section{Conclusion}

This article has argued that the recent rise of covenant-lite leveraged lending may mean that the next cycle of corporate restructurings looks very different from the financial restructurings which have dominated large corporate rescue since the financial crisis. It started by exploring the reasons for the rise in covenant-lite lending and argued that there are reasons to believe that covenant-lite terms may result in lenders and borrowers coming to the table later to commence restructuring negotiations in distress than has been the case when leveraged loans have contained financial maintenance covenants. It argued that this is not necessarily problematic for the particular institutions which have lent on these terms, but does give rise to borrower-level and potentially economy wide concerns which the current regulatory response to covenant-lite lending is not intended to address.

Thus the article argued that it is vital that we understand the implications of covenant-lite lending for restructuring practice, in considering whether we have the necessary tools in the corporate insolvency law toolbox to implement a different sort of restructuring from those which we have become familiar with since the financial crisis. The article has carefully identified the tools which may not have been needed for these familiar restructurings, but which may be needed in the next decade as a result of covenant-lite lending. At the time of writing, the UK Government has published its response to the Insolvency and Corporate Governance Consultation which proposes the introduction of three new tools into the English corporate insolvency law toolbox. However, the response contains very little on why the tools might be needed and how that might inform their design. This article has therefore concluded by using the detailed map of the tools which would be needed as a result of the rise in covenant-lite lending briefly to critique the current, draft proposals. This analysis suggests that the proposals require some further thought if they are to make English corporate insolvency law equal to the challenges which it is suggested lie ahead. 
